\title{
Necrotising enterocolitis in the very low birthweight infant: expressed breast milk feeding compared with parenteral feeding
}

\author{
F EYAL, E SAGI, I ARAD, AND A AVITAL \\ Department of Paediatrics, Hadassah University Hospital, Mount Scopus, Jerusalem
}

SUMMARY The incidence of necrotising enterocolitis (NEC) in very low birthweight infants (VLBW $\leqslant 1500 \mathrm{~g}$ ) was reduced by the delayed onset of enteral feeding. Eight (18\%) out of 44 VLBW infants who were in hospital during the first year of the study developed NEC. During the next 12 months 85 similar infants were initially fed by parenteral nutrition only, and then from age 14-21 days with infant formula. During the second year only $3(3 \%)$ patients developed NEC. There were no other relevant changes in management. Throughout the entire study, the onset of NEC in each infant in whom it occurred was after the start of enteral feeding. We recommend avoiding enteral feeding in VLBW infants during the period that they are particularly vulnerablenamely the first 2 or 3 weeks of life.

Necrotising enterocolitis (NEC) is a serious problem in very low birthweight infants (VLBW $\leqslant 1500 \mathrm{~g}$ ), and it was therefore of considerable interest when Barlow and colleagues ${ }^{12}$ showed that experimental NEC was prevented in a rat by feeding expressed breast milk (EBM). This finding was soon adopted and extrapolated to human newborn infants, ${ }^{3}$ and neonatal units renewed their interest in human milk banks. New criteria for collecting and using milk were suggested, ${ }^{45}$ but after a year of daily struggle to ensure fresh supplies of EBM for our VLBW patients, we were still encountering a considerable number of cases of NEC. A decision to change our feeding policy was made in accordance with the growing evidence for the role of enteral feeding in the pathogenesis of NEC. ${ }^{6-8}$ We present our experience during 2 consecutive years of early EBM feeding and delayed formula feeding in VLBW infants.

\section{Subjects and methods}

During two consecutive years, from May 1977 to April 1979, 342 newborn infants were in hospital in the newborn intensive care unit of this hospital. One hundred and twenty-nine (37.3\%) were VLBW infants $(\leqslant 1500 \mathrm{~g})$. During the second year, the number of admissions and the number of VLBW infants were almost double those of the first year (Table 1).

Table 1 Characteristics of the infants of very low birthweight $(\leqslant 1500 \mathrm{~g})$ during the 2-year period

\begin{tabular}{|c|c|c|}
\hline Infants & $\begin{array}{l}\text { First year } \\
(n=44)\end{array}$ & $\begin{array}{l}\text { Second year } \\
(n=85)\end{array}$ \\
\hline $\begin{array}{l}\text { Gestational age (weeks) } \\
\text { Birthweight }(\mathrm{g}) \\
\text { No of referred patients } \\
\text { No of infants }\end{array}$ & $\begin{array}{l}\text { Range } 26-34 \text {, mean } 28 \cdot 5 \pm 2 \cdot 0 \\
\text { Range } 705-1500 \text {, mean } 1167 \pm 238 \\
14(32)\end{array}$ & $\begin{array}{l}\text { Range } 25-34, \text { mean } 27 \cdot 5 \pm 3 \cdot 0 \\
\text { Range } 620-1500, \text { mean } 1046 \pm 210 \\
45(53)\end{array}$ \\
\hline $\begin{array}{l}\text { With Apgar score }<6 \text { at one minute } \\
\text { With respiratory distress } \\
\text { Necessitating mechanical ventilation } \\
\text { Undergoing exchange transfusion } \\
\text { Having umbilical artery catheter }\end{array}$ & $\begin{array}{l}14(32) \\
32(72) \\
26(59) \\
18(41) \\
40(91)\end{array}$ & $\begin{array}{l}28(33) \\
64(75) \\
50(58) \\
31(36) \\
76(89)\end{array}$ \\
\hline $\begin{array}{l}\text { Overall survival } \\
\text { Incidence of NEC }\end{array}$ & $\begin{array}{l}29(66) \\
8(18 \cdot 2)\end{array}$ & $\begin{array}{l}58(68) \\
3(3 \cdot 5)^{*}\end{array}$ \\
\hline
\end{tabular}

Percentages are shown in brackets.

$* \mathrm{P}<0.01$, Fisher's exact test. 
The feeding policy during the first 12 months was to use EBM exclusively for all VLBW infants. EBM was supplied by the infant's own mother or donated by mothers in the maternity department. The milk was pumped into a sterile glass container, and was used raw or refrigerated within 24 hours. Samples of EBM were sent randomly for culture. The feeding technique was continuous nasogastric or nasojejunal drip, starting on the second or third day of life. The daily increment was $10-20 \mathrm{ml} / \mathrm{kg}$ and the total intake was limited to a maximum of $180 \mathrm{ml} / \mathrm{kg}$ a day. Most babies were receiving at least half of their intake enterally by the end of the first week. The rest of the fluid intake was given as a $5-10 \%$ dextrose infusion.

During the second year the feeding policy was changed. Extremely low birthweight infants $(\leqslant 1000$ g) were not fed enterally before age 3 weeks, and those weighing 1001-1500 g at birth were not fed enterally until at least the 14th day, and some not until the 21st day. Feeding consisted of infant formula (SMA, Wyeth Laboratory or Similac, Ross Laboratory) in the same amounts and using the same technique as before. Total parenteral alimentation was used through peripheral veins to provide nutrition until enteral feeding took over. The amount of parenteral fluid was reduced gradually, according to the increase in enteral intake.

NEC was suspected if the characteristic clinical signs were present-namely abdominal distension, gastric residue, bile in the gastric aspirate, and bloody stools. The diagnosis was confirmed either by radiological evidence of pneumatosis intestinalis, free air in the peritoneum or the portal vein, or by pathological examination. Only patients who developed NEC in our unit were considered.

\section{Results}

Despite the increase in the number of admissions and the growing number of referred patients during the second year, the incidence of NEC in VLBW infants was reduced from $18 \cdot 2$ to $3.5 \%(P<0.01)$ (Table 1).

In VLBW infants who developed NEC, the age at onset of the disease was significantly earlier in the early EBM-fed group $(P<0.05)$ (Table 2$)$. During the entire period no case of NEC was encountered in any patient not fed enterally. The population of VLBW infants was similar in the 2 years for gestational age, birthweight, incidence of birth asphyxia, incidence and severity of respiratory distress, and frequency of umbilical vessel catheterisation (Table 1). Two of the 8 VLBW infants who developed NEC during the first year underwent surgery and 3 of the 8 survived. None of the 3 NEC patients during the second year needed surgical intervention and 2 survived.
Table 2 Infants of very low birthweight $(1500 \mathrm{~g})$ who developed necrotising enterocolitis during a 2-year period

\begin{tabular}{lcc}
\hline Infants & $\begin{array}{l}\text { First year } \\
(n=8)\end{array}$ & $\begin{array}{l}\text { Second year } \\
(n=3)\end{array}$ \\
\hline Gestational age (weeks) range & $26-30$ & $26-29$ \\
Birthweight (g) range & $705-1400$ & $800-1100$ \\
No of infants & 1 & 1 \\
$\quad$ With Apgar score <3 at one minute & 1 & 1 \\
$\quad$ With respiratory distress & 5 & 2 \\
$\quad$ Undergoing exchange transfusion & 2 & 2 \\
$\quad$ With umbilical artery catheter & 6 & $23-60^{*}$ \\
\hline Age at onset of disease (day) range & $7-24$ & \\
\hline
\end{tabular}

*P $<0.05$ by Fisher's exact test using a threshold.

During the same 2 years, 4 cases of NEC were encountered in patients with birthweight $>1500 \mathrm{~g}$. One of the 4 occurred during the first year, the other 3 during the second. The incidence of NEC in this birthweight group was 1.4 and $2 \cdot 2 \%$ respectively.

Thirty-seven of 43 EBM samples that were cultured grew saprophytic bacteria-such as Staphylococcus epidermidis or Streptococcus viridans, in concentration of $10^{4}$ or less per $1 \mathrm{ml}$. No potential pathogenic bacteria were isolated.

Routine cultures of the intravenous alimentation fluids were taken if bacteraemia was suspected. No case of bacteraemia was traced to parenteral alimentation.

\section{Discussion}

The incidence of NEC in our nursery was significantly reduced by instituting a policy of delayed feeding in susceptible preterm infants.

Although the exact aetiology of NEC is not yet defined, certain facts concerning its pathogenesis have been elucidated. The absence of the disease in stillbirths suggests it is an acquired condition. ${ }^{9}$ Many now believe that the pathogenesis of NEC depends on the interaction of 3 factors: disturbed intestinal mucosal integrity, the presence of pathogenic bacteria, and availability of a substrate to promote the growth of bacteria-namely food. ${ }^{710}$ Injury to the intestinal mucosa may be caused by a wide variety of temporary inevitable events that happen regularly in a newborn intensive care unit-such as asphyxia, shock, umbilical vessel catheterisation, and exchange transfusion. 71112 Prevention of bacterial overgrowth by the use of prophylactic antibiotics fed enterally has been advocated, ${ }^{13}$ but the hazards of emergence of resistant organisms ${ }^{\mathbf{1 4}}$ makes this suggestion potentially dangerous. The only factor that can be controlled satisfactorily is feeding.

Although the two modes of feeding in our nursery were not used simultaneously, the lower incidence of NEC in VLBW infants who received late enteral 
feeding is unlikely to be explained by the epidemic cluster of cases, characteristic of some outbreaks..$^{15}$ The incidence of NEC in our population of preterm infants with birthweight above $1500 \mathrm{~g}$ in whom there was no change in feeding policy, and who continue to receive early enteral feeding with formula or EBM actually increased during the second year.

The role of feeding in our patients is further stressed by the late occurrence of the disease during the second year, and the lack of NEC in all 85 late-fed VLBW infants, during their most vulnerable period-namely the first 2-3 weeks of life. ${ }^{712} 16$

The lack of protection of EBM against the development of NEC in human newborn infants has been reported previously. ${ }^{17} 18$ Trying to explain this failure, Kliegman and colleagues ${ }^{18}$ gave 3 possible explanations: contamination of milk by pathogenic bacteria, inappropriate antibody supply due to the use of EBM from women (including the mother) who do not share the infants' intestinal flora, and the effects of storage on the cellular components of EBM. We do not believe that milk contamination could have been a factor in our cases in view of the negative bacteriological findings, but the other 2 explanations may be relevant.

The progress in the use of parenteral nutrition has made it more acceptable for preterm infants, and the danger of bacteraemia has been reduced by using peripheral veins. ${ }^{19}$

VLBW infants are at greatest risk of developing NEC and our results suggest that it is safest to withhold enteral feeding in these susceptible infants during the first 2-3 weeks of life.

We thank Professor $\mathbf{R}$ Bloch for help with the statistical analysis and Professor S Godfrey for reviewing the manuscript.

\section{References}

1 Barlow B, Santulli T V, Heird W C, Pitt J, Blanc W A, Schullinger J N. An experimental study of acute neonatal enterocolitis-the importance of breast milk. J Pediatr Surg 1974; 9: 587-95.

2 Pitt J, Barlow B, Heird W C. Protection against experimental necrotizing enterocolitis by maternal milk. I. The role of milk leukocytes. Pediatr Res 1977; 11 : 906-9.
3 American Academy of Pediatrics Committee on Nutrition. Commentary on breast feeding and infant formulas, including proposed standards for formulas. Pediatrics 1976; 57: 278-85.

4 Williamson S, Hewitt J H, Finucane E, Gamsu H R. Organisation of bank of raw and pasteurised human milk for neonatal intensive care. $\mathrm{Br}$ Med J 1978; i: 393-6.

5 McEnery G, Chattopadhyay B. Human milk bank in a district general hospital. Br Med J 1978; ii: 794-6.

- Engel R R, Virnig N L, Hunt C E, Levitt M D. Origin of intramural gas in necrotizing enterocolitis (abstract). Pediatr Res 1973; 7: 292.

7 Santulli T V, Schullinger J N, Heird W C, et al. Acute necrotizing enterocolitis in infancy: a review of 64 cases. Pediatrics 1975; 55: 376-87.

8 Brown E G, Sweet A Y. Preventing necrotizing enterocolitis in neonates. JAMA 1978; 240: 2452-4.

8 Kosloske A M. Necrotizing enterocolitis in the neonate. Surg Gynecol Obstet 1979; 148 : 259-69.

10 Eidelman A I, Inwood R J. Necrotizing enterocolitis and enteral feeding. Am J Dis Child 1980; 134: 545-6.

11 Lifshitz F, Wapnir R A, Pergolizzi R, Teichberg S. Hypoxia (HY) effects on carbohydrate (CHO) transport (abstract). Pediatr Res 1976; 10: 356.

12 Bunton G L, Durbin G M, McIntosh D N, et al. Necrotizing enterocolitis: controlled study of 3 years' experience in a neonatal intensive care unit. Arch Dis Child 1977; 52: 772-7.

13 Egan E A, Mantilla G, Nelson R M, Eitzman D V. A prospective controlled trial of oral kanamycin in the prevention of neonatal necrotizing enterocolitis. J Pediatr 1976; 89: 467-70.

14 Nelson J D. Commentary on Egan E A, et al. A prospective controlled trial of oral kanamycin in the prevention of neonatal necrotizing enterocolitis. J Pediatr 1976; 89: 471-2.

15 Book L S, Overall J C, Jr, Herbst J J, Britt M R, Epstein B, Jung A L. Clustering of necrotizing enterocolitis. $N$ Engl $J$ Med 1977; 297: 984-6.

${ }_{16}$ Stoll B J, Kanto W P, Jr, Glass R I, Nahmias A J, Brann A W, Jr. Epidemiology of necrotizing enterocolitis: a case control study. J Pediatr 1980; 96: 447-51.

17 Reisner S H, Garty B. Letter: Necrotizing enterocolitis despite breast feeding. Lancet 1977; ii: 507.

18 Kliegman R M, Pittard W B, Fanaroff A A. Necrotizing enterocolitis in neonates fed human milk. J Pediatr 1979; 95: 450-3.

19 Benda G I M, Babson S G. Peripheral intravenous alimentation of the small premature infant. $J$ Pediatr 1971; 79: 494-8.

Correspondence to Dr F Eyal, Paediatric Department, Hadassah University Hospital, Mount Scopus, Jerusalem 91240, Israel.

Received 26 May 1981 